\title{
A Philosophical Interpretation of the Biopsychological Principles of Behaviour as Theory of Explanation in African Culture
}

\author{
Kidzu T. Oweh (Ph.D) \\ Department of Political Science and Public Administration, Adamawa State University, Mubi - Nigeria
}

\begin{abstract}
This work borders on attempts to provide a philosophical understanding into extant data about the influence of the physiological anatomy and genetic endowment on the human psyche. The aim is to contribute to the body of literature on bio-psychological principles of behaviour in relation to Africans and their culture. We took up the mind body problem as a complex phenomenon in the explanation of human behaviour in African societies. Research questions include: Are Africans indeed what they eat whose actions determine their behaviours?, Do their behaviours proceed from a healthy body to say that they possess a balanced body which has achieved health and, is in tune producing harmony? Are diseases affecting Africans not a consequence of undue tensions brought to bear on their bodies as a result of some improper tuning of the strings of their mind?, etcetera. Our procedure for pieces of information put together was the adoption of the secondary sources of research using philosophical analysis to interpret biological and psychological knowledge, while employing the rational-deductive method. The major findings show that Africans are by themselves, through themselves, also responsible to most of what has befallen them in conjunction with what slavery, slave-trade, colonisation and imperialism brought to Africa. The solution lies in a paradigm shift to occur in the minds of Africans with fresh substance of understandings about the world and Africa's position in the global drive to freedom, development and spiritual growth.
\end{abstract}

Keywords: Philosophy, Biopsychology, Behavioural Genetics, African culture.

\section{Introduction}

There have been myriads of explanation often given as reasons for our behaviour. These explanations range from the naturalistic, the historical, the philosophical and the socio-cultural perspectives etc. One perspective to the study of human behaviour in psychology, which is also more scientific and reliable out of the very many approaches, is known as the biopsychological principles.

Pertinent to note is the fact that the subject matter of psychology as a discipline of the social sciences, involves behaviour and mental processes which occur in form of actions and, or reactions. By action, we mean the product of spontaneous generation of conscious or sub-conscious reasoning or thought, while reaction refers to a solely conscious effort in response to stimuli or some primary actions.

The biopsychological principles make use of biological variables and data to explain how our mental processes and behaviour work. These principles stress the supremacy of our body over and above all other considerations in understanding what makes us behave the way we do, and why and how. Emphases are laid on the size and framework of our body as determinant of self-perception and self-assertion. It has emphasized that people with smallish-body framework most often than not, tend to be self-assertive in order to be noticed, and this kind of habit may build up into aggressive tendencies. There are also habits found with people having hugebody framework. The links of both the former and latter habits are traced to dieting mentality which, to a large extent, influenced behaviour.

This work therefore seeks to provide a philosophical interpretation on the extant data about the influence of the psychological anatomy and genetic endowment on the human psyche (the mind). The aim is to contribute to the body of literature on biopsychological principles of behaviour both as a specialised field of biology and field of psychology in relation to African culture. By that, we are re-enacting, by elucidating the mind-body problem as a complex phenomenon in the explanation of human behaviour in African societies. Our method is philosophically interpretational and deductive, adopting the secondary sources of research approachs.

\section{A Brief Philosophical Genesis of the Concept of Biopsychology}

The concept of biopsychology is a synergy of two specialised fields of biology and psychology, in an attempt to describe and explain the nature of life as it relates to both overt and covert actions of the living. Biopsychology is therefore a branch of psychology specifically known as "Biological-Psychology". In the Wikipedia, the free encyclopaedia, it is concisely captured thus:

In psychology, biological psychology also known as biopsychology and psychobiology is the application of the principles of biology to the study of mental processes and behaviour (2008:1). 
Philosophically, the conceptualisation of psychology earns its meaning from the works of Aristotle, the Greek philosopher and scientist. From the Greek psyche (essence of life or breath), translated to mean 'mind' and (logos), translated to mean 'study of', and in a bid to explain the components and meaning and essence of life to his students at the Lyceum, Aristotle taught the difference between inorganic and organic matter or bodies by considering the nature of the soul. The soul, according to Aristotle, is:

The first grade of actuality of a natural organised body. When a body is "organised," its parts have set motions to perform: thus, in a living plant, "the leaf serves to shelter the pericarp, the pericarp to shelter the fruit, while the roots of plants are analogous to the mouth of animals ... serving for the absorption of food." (Stumpf, 1982:94).

An implication from the above quotation is that since for Aristotle, the soul and body are one, the soul being the form of an organised body, man is therefore what he eats, whose actions, by parts of the body's set motions, determine his behaviour.

Biological psychology or psychological biology in this sense, from Aristotle, is a scientific adventure which studies the body, soul, mind or spirit. Psychology and biology have metamorphosed over centuries from Aristotle's perspective to become distinct disciplines read and applied in different higher institution of learning and organisations of different scopes and sizes. However, these disciplines have been viewed differently by thinkers and opinion builders or holders. While some view them from the humanistic point, others view them from the cognitive point, yet others from the socio-cultural and ecological, positivistic and behavioural point of view, etcetera.

The Pythagoreans, before Aristotle, viewed human behaviour as one that proceeds from a healthy body. Health for them, is the harmony or balance of the body that has certain 'conflicts of opposites' like hot and cold, wet and dry etc., which later became known in medicine as biochemical. For them, a balanced body is one that has achieved health, and is in tune, as it were best exemplified in music, where the different notes of the sounds produced harmony. In their opinion, "disease is a consequence of undue tensions or loss of proper tuning of the strings" of the body. And only "the proper balance of all elements and functions of the body" can one be said to be in good health (Stumpf, 11-12). In this case, health is determined by what one eats or the intake of food by the body in medical nutritional discourse, presupposing that our body energy conditions our actions (behaviours) that spring from it.

Aristotle, thus viewed the (body) vegetative soul as the nutritive soul. The nutritive soul performs the act of living which is the ability to take in matter (e.g. food), implying that life is contained in "self-nutrition and growth".

In more specific terms, we can decipher the fact that both biology and psychology are disciplines that study life as a whole. They are both sciences that study actions and reactions from the body to the mind, soul or spirit and vice versa, replicated in behaviour. This is perhaps why Lahey rhetorically asked:

Where do you live? You probably don't think about it much, but the thinking, feeling, and acting part of you has to have a body to live in. Psychological life depends on biological life for its very existence. This means that, the way we behave is influenced to a great extent by the nature of our body. If humans did not have hands to grasp, we might never have learned how to write, paint or play racquet ball. If we did not have eyes that could see colours, we would see a world that existed only in black and white ... (2001:53).

Lahey concurs that our behaviour is determined to a great extent by our body, and our body what we eat. This aligns with what Podjasek and Carney observed about our diet mentality as the state of mind that affected not only the way we perceive our body, but the food we eat to nourish it, to the way we perceive the whole self; body, mind and spirit (1998:1).

But, Avicenna (980-1037AD) in his Psychology, said there are "animated beings able to feel and move at will," but such ability does not come to them from their bodies. In his view, there is "a principle" that caused such aptitude of feeling and motion. The soul is that principle from which proceeds diversified actions due to a will. For him, a soul is a force, an energy and a perfection that perfects the genus with its specific determinations. The soul therefore is to him, the form of the matter which it makes to be in a living body. The soul replicates itself as a force, a form and a perfection. Avicenna is said to have followed the Aristotelian conception of the soul as a form of the corporeal body animated by the anima (soul), other than the platonic conception of soul as purely an incorporeal substance. The soul to Avicenna is, the form of its body, defined as 'a function' rather than 'a nature' (Gilson, 1955:198). Biopsychologically, Avicenna's interest is in 'the effect of the mind on the body." But our interest here rest in the complementary role of the mind and body. How the body also affects the mind by the behaviour. A corpus of research shows that Avicenna's work resonated with Descates's 'Cogito' centuries later, and what the phenomenologists called 'Epoche.'

His work bears a strong nexus between the body and soul, with the soul maintaining its individuation yet, keeping its incorporeality. On this account of psychological-biology the soul functions and relates with the natural body and its ability of perception (Wikipedia, the free encyclopaedia). 
Thus the philosopher gives explanation of the connection between the soul and body through his understanding of how perception interrelates bodily with the immaterial human intellect. The process of perception is the point of connection of the soul and body. This occurs during the body and soul interaction at the level of abstraction of the universal from the concrete particular as key to their relationship and interaction, all occurring in the physical body. Periscoping some of these pieces of philosophical genesis of the principle of bio-psychology from ancient Greek, (as it relates to the self; mind, spirit, soul and body) through the medieval to the modern period, the concept of mind or soul in ancient Greek evinced a broader and closer connection with basic body functions. In all of their view, the mind or soul gives light to the body and is the source of life. The soul is therefore responsible for the psychological processes, and also responsible for the biological functions and processes of the body as growth, respiration, digestion, motion and procreation (Kidzu, 2012:86-91).

\section{Principles of Behavioural Genetics and Problem of Genetic Influence in Behaviour}

Human beings are higher species of animals that are organised to carry out behaviours that help them survive and reproduce. Genetic influence on behaviour is any action that can be observed and described, reflecting in any other human-person who shows intermediate behaviour because such is inherited. This thus defines principles as "that which is inherent in anything determining its nature," and "a source or cause from which a thing proceeds" (The New International Webster's Comprehensive Dictionary of the English Language, 2004). Biologically, genetics in a sense deals with the interaction of the genes in manufacturing the similarities and differences between individuals related by descent. We are concerned here with the similarities and differences between individuals with such inherited characteristics they possess either as one person to the other, or as a group of individuals to another group.

The measurement of low genotype or genetic endowment in the chromosomes, also denoted as deoxyribonucleic acid (DNA) which children inherit from their parents, either one of the parents or both of them, depending on their level of recessiveness or dominance, influence behaviours and mental process. This is one reason why behaviour varies among species. It has also been noticed that similar behaviour persists across similar species. We find this in 'behavioural genetics'. Behavioural genetics adopts some comparative approach in the study of twins. This is done in terms of knowing whether they are monozygotic twins or dizygotic twins. Biological children and adopted children are also studied comparatively. All of this is for the reason of biologically determining whether they differ from each other somehow, apart from other environmental factors which shape behaviour. The task here is to actually determine the fact of which particular gene is tied to which particular behaviour. In other words, if a man or woman suddenly turns disorderly and runs amok naked, we should be able to reasonably tell which particular genes are causative to certain behaviours. The problem behind this is that, the intelligence quotient (IQ) of humans, for instance, is a very complex trait that cannot be simply tied to a gene. For example, some psychological research had shown that judges in courtrooms mostly think a defendant is guilty if the person appears to fit an intuitive profile of a person likely to commit a crime. This, according to the research is exemplified in situations where a poor young man from a poor home gets a sentence to jail for lack of representation, than an affluent criminally minded person who could probably be the real master mind of a crime (Coon and Mitter, 2010:302).

This position depicts how most often than not, some quick, impulsive thought that seldom recourse to clear reasoning could lead to dangerous detours other than contributing to creative problem solving mechanism. Creative reasoning or thinking allows that we employ and use all the thinking styles to solving routine problems. This will help us remove error of repeating learned solutions, but cause the innovative mind in the production of new answers, new ideas or patterns to each problem or challenge.

The underpinning of genetic influence on behaviour in this regard is all about heredity, and often used in metaphoric language as 'like father like son or like mother like daughter.' Granted all genetic influence on our human function, and if we understand the fact that a man or a woman is behaving the way he or she does due to the biopsychological nature the person is made of, then we would also have reason to excuse or assist such a person get same cure, assuming the behaviour is anti-social. Researches have shown that no two persons can behave similarly the same way. Not even monozygotic twins who share virtually the same genetic properties, let alone persons from different genetic roots. This leads us to the point of departure to our philosophical interpretation of such principles of human behaviours in African culture. The big question is, can Africans be excused for most of their negative behavioural lifestyles, caused, as we claim, by the impacts of slavery, slavetrade and colonialism?

\section{Biopsychological Principles of Behaviour in African Culture}

The sub-topic could be reconstructed to mean understanding the Africans' behavioural lifestyle, given their biopsychological nature. It is important to note the fact that what makes Africans behave the way they do is by far found in themselves than it is found and attributed elsewhere, and much more, as it is imposed on them from the outside world. It follows that Africans have been coerced to live under some unequal socio-global 
environmental forces, but yet, are predisposed to act or react differently at different times and situations, which implies that the functioning of Africans' physiological anatomy and genetic endowments is absolutely different from others. This is perhaps why attempts by different people have been made to give explanation on how phenomena occur and the way they do. The many statements or propositions or generalisations on occurrences of phenomena could be regarded as theories. A theory is aptly described as an attempt to explain events, forces, martials, ideas and behaviours in a comprehensive manner. A "set of statements that seek to explain problems, actions or behaviour." An effective theory should possess some explanatory as well as predictive power (Schaefer, 2003:9).

Thus, the African culture could be defined as a set of statements that seek to explain the problems, actions and behaviour of Africans within their given environments that may or may not be peculiar to some other cultures of the global divides. Though there are said to be over two hundred definitions on the idea 'culture' yet, it reflects itself as a phenomenon for the African people. In ancient times, culture was known as an act of soil cultivation. The ancients saw it as a way of improving nature through the exposition of its primeval beauty and might (Guverich, 1989:8). The medieval people identified culture as the urban way of life. It was identified in the renaissance era as the humanistic ideal of man. Modern civilisation recognised culture as the level of advancement of the spiritual and practical knowledge of individual people of the world. This gives room how culture is identified in the western world with spiritual standards of values, traditions and other features of social interactions or relations. But in Africa and Asia, culture is perceived as both spiritual and material worldviews. That is why it has been said that "to know how a people view the world around them, 'is to understand how they evaluate life, and a people's evaluation of life both temporal and non-temporal provides them with a charter for action, a guide to behaviour"' (Ezechukwu, 2004:65).

Ontologically, philosophy taught us that "necessary beings would have distinct existences, so would their essences. Two essences cannot be both different and necessary ... In order to be different, one of them must have something which is not to be found in the other one ..." (Avicenna in Gilson, 208). This is how nature and the Creator so allow it to be. Africans, by their natures have the existence that describes their essences which distinguish them from other existences of the world. That they have dark colour proceeds from the essence of their blood gene which produces the darkness that gives their colour. What makes them behave the way they do is responsible to the essence of their form. They can only learn to behave white but cannot be white since their essences follow their genes. Contrariwise, the whites could also learn to behave dark but would never be dark since their essences are white. If any of these categories so do by themselves otherwise, that would mean nature contradicting itself by order.

The questions are, are Africans indeed what they eat, whose actions determine their behaviour? Again, do their behaviours proceed from a healthy body, to say that they possess a balanced body which has achieved health and is in turn producing harmony? Are diseases affecting Africans not a consequence of undue tensions brought to bear on their bodies as a result of some improper tuning of the strings of their soul? Could Africans actually determine their health by what they eat, so as to produce that healthy body and soul (man) that can produce the global energy required to compete globally in the scientific and technological arena? How has the physiological anatomy and genetic endowments affected the African mind?, so much so that the size, weight, height and colour, had caused them not to think well and positive too, in order to remove all the negative tendencies that come with them either by the nature of their birth or through other environmental forces with time. But has Africa what it takes for her culture to be the pace-setter of other cultures of the world? Are Africans not by themselves helping to decimate the very cradle behind other civilisations of the world? Have we not glorified corruption to stand as the saviour of the continent?

How we understand the Aristotelian notion that man is what he eats whose actions and body movements determine his behaviour is on the negative. Here, Aristotle, infers good health and fine living that proceed from good standards of life and societal norms of good behaviours. But our crave and desire for vitality and pleasure have moved us to a mind-set which accompanies fixed evil; yet driving Africa to the negative goal of life. This is in tune with Hobbes's assertion on the human nature about each one with his own concept of pleasure, pain, good or bad, as every reaction of man is with reference to the environments around him (Mukhi, 2007:423). Because Africans are desirous of showing that each man is what he eats, they tend to trade their universal equality of intelligence for desire to have the same thing as the other man has. This has led them to quarrelling and fighting with themselves while recruiting others to help destroy themselves and the environments.

Africans, and the desire for crass materialism and excessive competition, and concern to make a difference in lifestyle through some negative means, triggered economic epidemics of some sort which have been attributed to be the cause of endemic behavioural affliction plaguing the continent. We keep trading blame and cast aspersion on Western culture as the cause of developmental epidemics that have come on us, and the West being responsible for much of our economic woes, by reason of their conscripting us to assimilate and be assimilated into a mix of foreign cultural values and categories of exposition of their existential experiences other than African. 
We need more of the philosophical analysis which emphasised "the rapidly changing concepts of human nature," in order to rewrite the remarkable complexity of human beings, to give room for further exploration of the human genome granted rising evidence that each man is what he is as a result of the genetic make-up, man's current environment and such long history of the cultural values handed down to us (Ogar, 2011:5-6). While we also accept the fact that environmental experiences and birth shaped our behaviours, we equally cannot dismiss the position that some behaviours about Africans seemed to be stereotyped. Africans have to be excused on this by the reason of environmental and birth situation they find themselves in.

True, our behaviours smack of lots of moral credibility, but we still cannot absolve completely the Western culture, of having also influenced the African character through practice, by learning a lot of what is counter-productive to the African culture. Like the biological laughing gull, Africans have adopted the begging behaviour following the economic impoverishment of her economy during and after the slave-trade and colonial eras. Even after political independence, African countries continued to demonstrate the pecking-motionresponse towards their paterfamilias colonial masters' beak stimulated towards Africa's begging behaviour. A positive response from Africans would persuade the West to regurgitate food on the floor of Africa. A negative response would necessitate negative responses which would force Africans to starve and somehow, get back to the drawing board to learn never again to misbehave negatively towards their parents (the West). Experience has taught Africans how to behave by a remodelling of the behaviour with what they have learned, if they must survive.

The interaction between Africa and Europe suggests the begging behaviour that involves learning, which must be a continuous exercise for Africans. In this regard, the biological method of dominance hierarchy is what must continue to be foisted on Africans. The dominance hierarchy connotes that higher ranking animals in a troop would have greater access to resources than other lower ranking animals. Dominance is always decided by confrontations, paving way for the dominant animal to override the others (Mader, 2000:677). America and Europe would continue to turn their behaviours on us until we evolve our own techo-cultural superiority that will match their territorial and global dominance cultures.

Yet still, that Africa is diseased as a consequence of undue tensions and pressures brought to bear on her culture do not put all the blame on such other cultures that came with some cross-fertilisation. Otherwise, history records that during slavery and slave-trade in Africa, the transactions on human beings in Africa sprang up long before Christianity and Islam (though tacitly supported by these religious institutions and authorities) on the African soil. It is noted that in ancient Egypt, slaves were employed both for work and for the building of pyramids. The Nubians of southern Egypt were sold out of Africa by Africans themselves. Ethiopia has stories of slave sold out by themselves according to Greek and Roman records. Reference is also made of the Sudanese Empire how slaves were sold to Carthage. History is replete with historical records of East Africa on slaves sold to Turkey and Persia. The old Ghana Empire with capital at Kumbi was notorious for its slave market. In Mali, the aristocracy sustained a large number of slaves etcetera.

It is on record that the practice of slavery and slave-trade were rife within Africa long before European contact with the rest of Africa. Africans themselves were already engaged in the merchandise of slavery and the trade in it within Africa long before its extensive progress by the advent of the white-skinned man. This is why Oguejiofor conceived that "it would be wrong to discuss the trans-Atlantic trade in such a way as to suggest that it was a misfortune perpetrated on the African continent wholly by outsiders" (2001:28). Taking a leverage from the facts above, with an understanding of culture here as a way of life of a people, nobody thus forced Africans into this culturally retrogressive behaviour when African rulers and chiefs put their fellow Africans captives and negotiated with buyers from outside for sale of these captives. In fact, it is also evident that it was until when the white merchants who came into Africa, specifically for the exploration of gold and other minerals and trade items of cash crops discovered how lucrative slavery and slave trade were that they switched gear.

Indeed, many unwholesome behavioural attitudes of this nature permeated the whole land-scape and culture of Africa. The record of killing of twin babies and ritual sacrifices for which Mary Slessor, the Scottish Missionary gave her life is still fresh. Nobody forced Africans into this side of inhuman cultural behaviour even to this $21^{\text {st }}$ century, as the global community is now driving towards progress; but leaving behind most of these barbaric acts of old. Most of the rest of the world had progressed to a refined society today.

Long after historical and political colonisation, Africans still engage in various imperialistic tricks among themselves and against themselves. Africans continue to enter trade agreements and practices, even deceptive languages and protocols that suggest the old habit of suppression. A system where others manipulate the will of others to get them up the wrung of society. Kalu has this to say:

In Africa, there's the dysfunctional system where people move up the leadership ladder on the basis of mundane considerations like whose son or daughter you are, not on the content and quality of character (2013:14). 
The culture of looking at the physiological status (size, height, weight and framework) of a person before we accord him the respect he deserves is incorrect. This kind of perception and assertion we give people, by reason of their status in society, creates a culture of dehumanisation and negation of the other.

The elite Africans have persisted and created a society of behaviour where the rich parvenus keep growing fatter while the poor keeps becoming leaner and leaner. This brings us to the law of the sea and fish. In the traditional notion of the law of the sea, there was a laissez-faire kind of freedom, openness and unrestricted use of the sea. The openness and freedom exist because they serve the interest of the dominant maritime powers of the time, for navigation and fishing. Smaller sizes of ships and fewer abound, and nobody complained of depletion of fish stock since the resources were inexhaustible. But when the challenge came by the emergence of the superpowers in the $20^{\text {th }}$ century against the dominance, partly as a result of growing nationalism and demands for economic freedom by the developing states, and the technological breakthrough, coupled with increased demand for the resources of the sea, conflict now replaced the freedom and restrictions were created (Tagowa, 2010:3-5). As the hitherto open and free waters became under control and artificial boundaries created with restrictions, the environment and natural habitat of the fish became troubled. The fish also have to adapt by this adjustment of the natural habitat by man. They also created regions where other big fish and smaller fish must swim. No lesser fish dares the restricted region, else such fish had decided to take the risk and fate to be swallowed up by the big fish.

The rule is simple. The big fish eats and consumes the lesser fish in order to stay alive and grow bigger. The principle stipulates that if you must stay big and live like a king, eat big. And if you must eat big, go for more, and as you go for more your life is determined by what you eat. Africans have the capacity of colonising and redominating themselves mentally and physically. Africans have argued severally that knowledge is universal, but never a prerogative of any one culture. Cogently enough, this is one of the reasons now why they try to sing a faulty but unanimous song to the global community of their home grown knowledge-based ability to do things their own way, most of which do not fit the universal standard of the global humanity.

The big fish attitude is a correct reflection of the gullible character Africans are disposed to. It is true that our natural inclination to the gullible mind-set to certain goods and services which are foreign had tailored us towards a perpetually dependent people who make false claim about their being. We are determinants of erroneous self-perception and assertion. We want to live what we eat but leaning on a physiological nature of consumerism which inhibits a focus-orientated driven mind. We have allowed the demonic mind instead, caused and driven by lust and taste for things our minds can only imagine but the body cannot produce or manufacture. A mind that spends money (in spite of the enormous poverty in society) on big things we do not really need. Instead of investing in things that will help develop the African economy and make good the living standards, and cause circumstances to improve, Africans rather grab from their environment and waste resources with reckless abandon. We steal from the cultures, carting wealth away from the teaming poor masses (Alibi, 2013:56).

We Africans, have failed to realise we are treading on the wrong side of behaviour when we engage in the business of exporting crude oil but importing fuels and petro-chemicals, exporting iron ore but importing steel, exporting alumina but importing aluminium products, exporting raw cocoa but importing processed cocoa products, exporting cotton but importing garments (Omoh, 2013:19). All this tells who we are by what we eat.

\section{The Antidote to Our Principles of Behaviour}

In answer to his question on what must be done to salvage Africans with their Africa, from epistemological backwardness, Ozumba, asserts that "there is a lot to be done to make Africa epistemologically relevant." Buttressing Omoregbe's argument, he said:

Human nature and human experience are basically the same all over the world and the tendency to philosophise is part of human nature ... all humans reflect on some fundamental philosophic questions about life or about the physical universe (2004:40).

Centuries ago, the French philosopher, Rene Descartes, had admonished that it is useful that we know something of the manners of different nations in order that we may be enabled to form a more obvious and correct judgement regarding our own and be prevented from thinking that everything contrary to one's custom and culture is irrational and ridiculous. For him, this is a conclusion usually made by those whose experience has been limited to their own country. He said the overcurious in the customs of the past are generally ignorant of those of the present (1974:42).

Fundamentally too, on his prescriptions and idea about "the new Africa" envisaged, the great Zik of Africa, also admonished in his gospels on what must be done for the emancipation of Africans and their Africa. According to him, the renascent Africa which he preached was not to be a movement, and as such, Africans must not be tempted to fall into a common error of expecting a new continent geo-physically. The new Africa must be one with "a state of society where the mind is brought into harmony with matter. The new Africa must be that which cooperation exists while the old order will have passed away. The new Africa is a position of the 
mind which is deeply rooted in a material environment. Thus, as the kingdom of God cannot be decided along material lines, Africans must not enter a mind-set which is grounded on a material environment. Therefore, Africans must achieve mental emancipation, and get over the barriers of race or tribe (Mutiso and Rohio, 1987:16)."

In the realm of politics, we have witnessed a myriad of culture of impurity in behaviour. Dissent to political views is interpreted as subversion to leadership, most often, greeted with punishment of some sort even death. Though every culture has its very peculiar nature, some to the good and others to the bad, yet we cannot deny the fact to say that the configuration of cultures (Western-Christian, Islam Science, Technology and Industrialisation) on the African soil did not give us the opportunity to also learn the good side of them. Although Timberlake's comment on R. Dumont's False Start in Africa, warned that European solutions are not the answer to black African's problems, we still cannot dismiss the fact that it is in our ability to appreciate this cultural mix that we would be able to amend the evil side of behaviour in our culture. We can pull this up from our perspectives to the universal pedestal of experience through reason to place Africa back to the foundation of her primordial existential humanism in the global setting (Kidzu, 2004:102-103).

Somehow, it seems Africans will need more forensic experts using our African categories, to get back to our forefathers' tombs, to excavate their bones for test on DNA whether this has changed with time, nature and environmental situation. Perhaps this may give us some clue to the solution to our pathologically pandemic behaviour of non-resurrective retrogresiveness. That we had often used our presumptuously disadvantaged position argument, in virtue of our biological birth and psychological mind-set inability as reason for our behavioural misdemeanour, is no longer acceptable in the $21^{\text {st }}$ century civilisation. We have enormous thought of how Africa was the cradle of civilisation, but, for how long? If we claimed to have intelligence to turn things forward and not backward (as is our behaviour), then we should be able to explicate the point that the global capacity to act purposefully, think positively deal effectively with the environment defines that intelligence (Sternberg, 2004:325).

That Africa has a rich culture with men of good behaviours is also not a fact in dispute. An attestation to this fact is the justifiable reason why Africans, with high cerebral endowments of intellectualism, are often brain-drained to work in other international and foreign cultures cum organisations and governments. Their expertise in the various fields of endeavour shows that the black-race is made up of some stock of the rational gene of life like every other human race on the face of the earth. The difference between the white race and the black race is the blood gene, granted the scientific and technological edge, most of which Africans were the bondsmen behind the success. This difference, much less than similarly with the white human species, in terms of propagation and direction of knowledge, put one in perpetual doubt whether a recalcitrant demon was not responsible for our being out of creation. Perhaps the very type that was responsible for Descartes's Cogito.

Ordinarily, Africans seemed to have accepted the decision of fate on themselves. Otherwise, what would have kept them on the lamenting ground for so long without acting? If the claim stands on the fact of slavery and slave trade, colonialism and neo-colonisation etcetera, (which are indices of domination) then we would also have been able to learn from the hard vicissitudes of life to emerge from our multiple developmental backwardness, using the very trick we have learned from Western culture, to reposition ourselves in the global sphere, since globalisation allows everyone to showcase talent. I think, and rightly too, that all we have just been involved in is an attempt at self-assertiveness in order to be noticed, without confronting the challenge cooperatively as a people with a particular aim and destiny for regeneration. Africans must rise to the challenge of development across the world. This we can do if we resist the character of gullibility that has plagued us. We have negated and relegated ourselves, but, complaining that all that is America or Europe, as bane to our development.

Africans must put behind them the spirit of lamentation four hundred years after, over and about how Europe underdeveloped Africa. How long must this behaviour continue? What this means is that we have adopted psychological idleness yet, to tell stories and revolving our history past in the present, and never getting back to the future. Getting back to the future means to get back to the beginning and take those cherishable customs and traditions that shaped our reality, into the present and built them into the future. That is, Africans must begin to think and reason backwards in the present on the future by acting locally but performing globally.

Rather than keeping to this spirit of lamentation, Africans should learn the story of the Hebrews, of what they did while in exile. Four hundred and thirty years after, they came out strong. While they were in bondage on African soil, they were never hopeless, but strong and hardworking under (we) their bond masters' directives. That experience became their learning curve for life. They kept their resilient nature to put them through all the rigorous body-diminishing conditions. In all this, they hard great expectations through hard work, honesty and trust in their Creator. They kept moral decency, trustfulness and holiness to God, the point at which sin was greatly punished.

Africans must not continue to allow their body conditions to sway them through crass materialism resonating with destructive mental detours which do not contribute to creative problem solving mechanisms. We 
should accept the fact that Africans are part of their problems. We should be able to learn from a whole complex of cultural mix and clash, to come out to do, to use, to produce and believe that we can progressively and comprehensively grow innovatively like other advanced cultures (Tischler, 2011:51). The white human beings are like every other human creature, except for their capacity to explore, conquer and exploit. This, they are, because they must eat, sleep, walk, have shelter and protect themselves from the vagaries of life and the environment. They must reproduce, nurture their young ones and keep the virtue of living, except they had refused to survive as a species. These are biological principles.

Africans are also a species with basic biological ways which are identical except for the inherited behavioural patterns which have caused mental slumber and sluggishness not to go out and explore, conquer and exploit, while adopting similar categories of discovery. Our biological lifestyle had influenced our psychological ability to reason. We consume that much and think less, except for some very few who have distinguished themselves at the global arena.

Africans must collectively emancipate themselves from all behavioural psychological-bionegativity, as well as decolonise themselves from all "social engineering gimmicks" (Oguntola, 2013:58), and ethical/tribal demarcations; but begin to apply their creative ingenuity in science and technology to their positive advantage, the type which could lead them to attain economic and cultural independence to rule the world either in this $21^{\text {st }}$ century or the $22^{\text {nd }}$ century to come.

\section{Conclusion}

We have attempted to interpret the behaviour of Africans through their actions using biological and psychological understanding of human nature. We posed a challenge to say that Africans are by themselves, through themselves, responsible to most of what has befallen them in conjunction with what has been imposed on them through slavery, slave trade and colonialism and imperialism. A challenge to all Africans on the need for us to regenerate ourselves, to explore and utilise the great potentials that characterise the African mind. A more progressive way of behaviour and shift from the hitherto unsophisticated ' $\mathrm{I}$ ' alone must have all attitude. This we must acknowledge not to neglect the fact about the cause of our spiritual, technological and economic backwardness.

Our dimension in this direction is informed by the understanding that we have not done justice enough to ourselves. The issues being interpreted here appear to be obvious and clear. We should by now be able to redirect our minds towards rewriting our negative historical past by obliterating and correcting our culture and any falsified image foisted on us. This involved a paradigm shift to happen in the minds of Africans based on fresh, fundamental understandings about the world, Africa's place in the world and how Africans, by themselves can alter Africa's trajectory.

\section{References}

[1]. Alibi, I. (2013). "Let us go the Asian Way (2).” Daily Trust, 22 August, 32 No.84.

[2]. Coon, D. And Mitterer, J. O. (2010). Introduction to Psychology. Gateways to Mind and Behaviour (Twelfth Edition). Australia: Wadsworth, Cengage Learning.

[3]. Descartes, R. (1974). The Rationalists (Translated). New York: Anchor Books Doubleday \& Company, Inc.

[4]. Ezechukwu, P. O. (2004). "Appreciating the Different World Views In African Tribes: An Exposition". A Colloquium on African Philosophy. Vol.2. Ed. G.O. Ozunba. Calabar: Jochrisan Publishers.

[5]. Gilson, E. (1955). History of Christian Philosophy in the Middle Ages. New York: Random House.

[6]. Guverich, P. (1989). Man and Culture, Man in the Modern World (Translated By Mikhail Nikolsky). Moscow: Novosti Press Agency Publishing House.

[7]. Kalu, P. C. (2013). "Femi Fani-Kayode is not a Man of Class" Nigerian Pilot. 19 August, 3 No. 620.

[8]. Kidzu, T. O. and Ncha, G. B. (2012). "Synoptic Excursus of Ancient Greek Concept of Mind From Thales to the Stoics" Research on Humanities and Social Sciences. Vol.2 No.5.

[9]. Kidzu, T. O. (2004). "Kwasi Wirdu's Conceptual Decolonisation in African Philosophy: A Review" A Colloquium on African Philosophy. Vol.2 Ed. G. O. Ozumba. Calabar: Jochrisam Publishers.

[10]. Lahey, B. B. (2001). Psychology: An Introduction (Seventh Edition). New York: McGraw Hill.

[11]. Mader, S. S. (2000). Inquiry into Life (Ninth Edition). Botson: McGraw-Hill.

[12]. Mutiso, G.C.M. and Rohio, S. W. (1987). Readings in African Political Thought. London: Heinemann Educational Books Ltd.

[13]. Ogar, J. N. (2011). "Introductory Note" Introduction to Philosophy of Medicine. Ed. Asira E. Asira and Joseph N. Ogar. Calabar: Jochrisam Publishers.

[14]. Oguejiofor, J. O. (2001). Philosophy and the African Predicament. Ibadan: Hope Publications Ltd.

[15]. Oguntola, S. (2013). "Social Engineering Gimmicks" The Nation, 1 September, 08 No.2595.

[16]. Omoh, G. (2013). "What Is Wrong With Nigeria and its Leaders" Vanguard. 19 August, 25 No.61949.

[17]. Ozumba, G. O. (2004). "Whither African Epistemology?" A Colloquium on African Philosophy Vol.2. Ed.G. O. Ozumba. Calabar: Jochrisam Publishers.

[18]. Podjasek, J. H. and Jennifer, C. (1998). The Ten Habits of Naturally Slim People and How to Make Them Part of Your Life. Chicago: Contemporary Books.

[19]. Schaefer, R. T. (2003). Sociology (Eight Edition). New York: McGraw-Hill.

[20]. Sternberg, R.J. (2004). "Culture and Intelligence" American Psychologist, 59(5).

[21]. Stumpf, S. E. (1982). Socrates to Sartre: A History of Philosophy. New York: McGraw-Hill.

[22]. Tagowa, W. N. (2010). Continuity and Change in the Law of The Sea. Kaduna: Pyla-Mak Services Limited. 
[23]. The New International Webster's Comprehensive Dictionary of the English Language: Encyclopaedic Edition (2004). Florida: Trident Press International.

[24]. The Wikipedia, The Free Encyclopaedia (2008) (www.en.wikipedia.org /wiki/behaviouralgenetics).

[25]. Tischler, H. (2011). Introduction to Sociology $\left(10^{\text {th }}\right.$ Edition). Australia: Wadsworth Cengage Learning. 